\title{
Assessment of Urban Sprawl Using Geospatial Techniques in Awka Town, Anambra State, Nigeria
}

\author{
Banki T. Chunwate1, Sani Yahaya1, Charles O. Amankwe1, Ademu Samuel2, \\ Benbella Ruth Madaki ${ }^{3}$ \\ ${ }^{1}$ Department of Geography, Nasarawa State University, Keffi, Nigeria \\ ${ }^{2}$ Department of Geography, Kogi State University, Anyigba, Nigeria \\ ${ }^{3}$ Department of Geography, College of Education Akwanga, Akwanga, Nasarawa State, Nigeria \\ Email: optimistbanki4u@gmail.com, yasani247@yahoo.com, hawasam30@yahoo.com, madakiruth84@gmail.com
}

How to cite this paper: Chunwate, B.T., Yahaya, S., Amankwe, C.O., Samuel, A. and Madaki, B.R. (2019) Assessment of Urban Sprawl Using Geospatial Techniques in Awka Town, Anambra State, Nigeria. Journal of Geographic Information System, 11, 359-370.

https://doi.org/10.4236/jgis.2019.113022

Received: May 24, 2019

Accepted: June 16, 2019

Published: June 19, 2019

Copyright $\odot 2019$ by author(s) and Scientific Research Publishing Inc. This work is licensed under the Creative Commons Attribution International License (CC BY 4.0).

http://creativecommons.org/licenses/by/4.0/

\begin{abstract}
Cities and towns in developing countries are experiencing an unplanned and uncontrolled development known as urban sprawl. This research examines urban sprawl in Awka metropolis, between 1986 and 2016. Landsat 5 Thematic Mapper (TM) of 1986, Landsat Enhanced Thematic Mapper plus (ETM+) data of the year 2000 and Enhanced Thematic Mapper plus (ETM+) 2016 were used for this study. Geographic Information System was employed for the analysis of the data. Result showed that Awka metropolis witnessed a remarkable growth between 1986 and 2016 from mere $3444.48 \mathrm{Km}^{2}$ in 1986 to about $11,452.46 \mathrm{Km}^{2}$ in 2016 . This growth contributed to the sharp decline in farmland from $25,500.51 \mathrm{~km}^{2}(19.13 \%)$ in 1986 to $17,848.44 \mathrm{~km}^{2}$ (13.60\%) in 2000 and further declined to $10,037.07 \mathrm{~km}^{2}(10.01 \%)$ in 2016 . Bare surfaces witnessed an increase over the years of this study. This increase is as a result of clearing of natural vegetation for urban development, thereby exposing the land to direct contact with rainfall, leading to gully erosion in the area. Light vegetation also witnessed a sharp decreased from (38.53\%) in 1986 to $(8.53 \%)$ in 2000. It further decreased (8.53\%) to $(4.62 \%)$ in 2016 . Therefore, increase in population led to the increase in urban sprawl in the study area. The study recommends that there is a need for a regular monitoring of urban sprawl and development in the study area by the state government especially with the aid of geospatial techniques for better decision making.
\end{abstract}

\section{Keywords}

Urban Sprawl, Landuse/Cover, Population, Change Development, GIS 


\section{Introduction}

Cities and towns in developing countries are experiencing rapid population growth and uncontrolled development known as urban sprawl. For the first time in history the urban population of the world has outnumbered the rural population (Badiane, 2006) [1]. This epochal transition occurred mostly in Africa and other developing countries of Latin America and Asia. In fact, the world has urbanized faster than originally predicted by T.R. Malthus (1978) [2]. In 1950, there were 86 cities in the world with a population of more than one million (Badiane, 2006) [1].

Sprawl takes place either in radial direction around a well-established city or linearly along highways (Torrens, 2006) [3]. Patterns of sprawl and analyses of spatial and temporal changes could be done through various methods. The Mapping process provides a "picture" of where this type of growth is occurring, which helps to identify the environmental and natural resources threatened by such sprawls, and to suggest the likely future directions and patterns of sprawling growth. The effects of sprawl on agricultural land use and other land uses such as residential, commercial, industrial and institutional are other concerns that are dependent on the mapping and study of the sprawl process. Ultimately, the power to manage sprawl resides with local government authorities that are saddled with the responsibility of urban developmental control.

Urban sprawl is often uncoordinated and extends along the fringes of metropolitan areas with incredible speed. Commonly, this uncoordinated development encroaches agricultural and resource land uses in the process. Land is often developed in a fragmented and piecemeal fashion, with much of the intervening space left vacant or in uses with little functionality (Torrens and Alberti, 2002) [4].

Sprawl in Nigeria consists of informal housing developments on the urban periphery, on land that is mostly privately owned, sold in single small plots. These newly developed areas have been called peri-urban areas (Imhoff, 2000) [5] and the inter-metropolitan periphery (Berry, 1990) [6]. The ex-urban areas beyond the suburbs are sometimes called fringe developments (Daniel, 1999) [7] and extended places (Bureau of the Census, 2000) [8].

The study on urban environmental issues using remote sensing and GIS techniques in India, indicated major urban environmental problems that occur due to high population growth (the $46.31 \%$ increase during 1991-2001). Also, the uncontrolled and mismanaged urban expansion has led to the doubling of the densely built-up area during the last decade in Delhi (Atiqur, Maik, Alka, and Javed, 2009) [9].

All cities in Nigeria are experiencing sprawl; Awka metropolis is not an exception because of the scale and type of development on some of the city's most agriculturally productive land. In the past decade, the city's built up area burst outward in an explosion of sprawl that consumed former agricultural land at a break-neck pace (Lazarus, 2012) [10]. Hence there is a need to examine the na- 
ture and the pattern of sprawl in the area, for proper decision making and thereby, to enhance sustainable development.

\section{Materials and Methods}

Awka town is located between latitudes $6.20^{\circ} 22^{\prime} 24^{\prime \prime} \mathrm{N}$ and $6.28^{\circ} 32^{\prime} 34^{\prime \prime} \mathrm{N}$ and longitudes $7.00^{\circ} 04^{\prime} 04^{\prime \prime} \mathrm{E}$ and $7.08^{\circ} 04^{\prime} 04^{\prime \prime} \mathrm{E}$ on the Southeastern part of Nigerian. Awka is bounded with Nibo in the south west, Mbaukwu and Okpuno in the north east and then Umuawulu, Isiagu, Ezinato, in the south east as shown in Figure 1.

Landsat 5 Thematic Mapper (TM) data of 1986 and 2016 with spatial resolution of $30 \mathrm{~m}$ with band 8 of spectral bands with a spatial resolution of 15 meter were obtained from the Global Land Cover Facility (GLCF) and Earth Science Data Interface. All images were clipped out according to the study area by using "Subset" function in ArcGIS 10.1. Ground Control Points (GCPs) were collected through an extensive field survey throughout the study area using Global Positioning System (GPS). ILLIWIS 3.3, ERDAS IMAGINE 9.2, ArcGIS 10.1, MS Excel, Microsoft Office were used to extract and classify the land use and land cover of the study area. Results were summarized in tables, figures and were discussed using descriptive statistics.

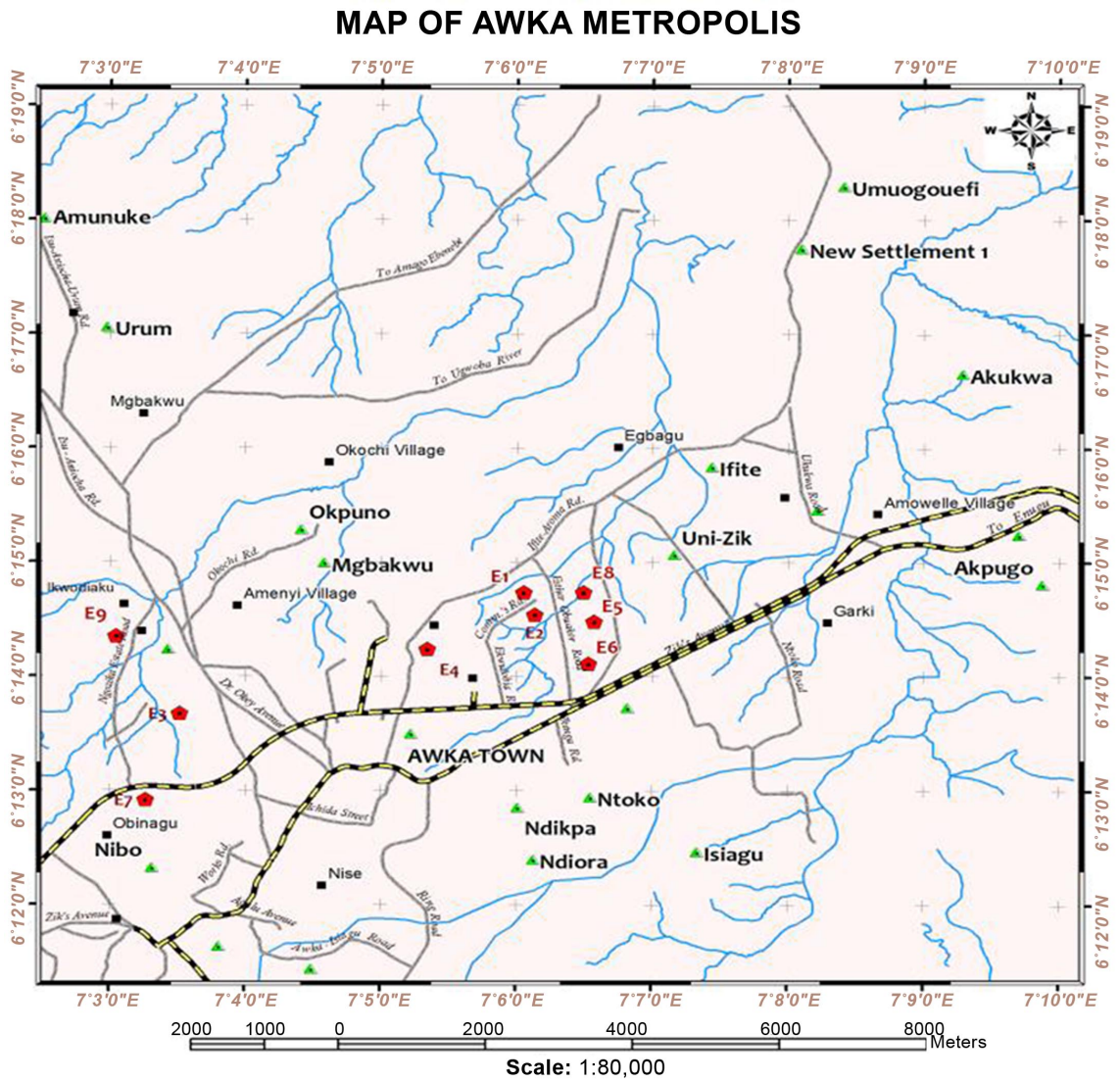

Figure 1. The study area (Awka). Source: Anambra State Geographic Information System (2018). 
After the images were geo-referenced and geometrically rectified, Image clipping was performed using spatial analyst tool on a sub-scene from the full image on the basis of a frame covering the area of the study. These preprocessing tasks allowed the export of the satellite images to the ArcGIS and ERDAS for classification and extraction of land use and land cover information. Supervised classification was performed on the same images, with random training samples using on-screen digitizing from on the standard menu of the software; Land cover types classification and identification were performed. The 1986, 2000 and 20116 images provided a means to determine LULC in the categories; built-up, bare surface, vegetation (light and dense), and farmland.

The area coverage for each land use/land cover types was calculated for the years covered by this study. This was done to generate a table showing the area in square kilometers and the percentage change for years 1986, 2000 and 2016.

To detect changes in the land use/cover at different years, post classification comparison of the change detection techniques was used. The various land-use/land-cover types are modified into five classes namely; built-up, bare surface, vegetation (light and dense), and farmland (Anderson, J.R., Hardy, E.E., Roach, J.T. and Witmer, W.E., 1976) [11].

To determine the extent of urban land use between 1986 and 2016, the attribute and statistics from the classification result was generated and used for post-classification comparison among the years. The built-up was also extracted for each of the periods and the extent of the built up area was calculated in $\mathrm{km}^{2}$. The extent of urban sprawl between 1986 and 2016 was analyzed by subtracting the reference year of land cover of 2016 from the base year 1986. To determine the rate and pattern of urban sprawl in the study area, tables were used to show the rate of urban sprawl using the resulting value generated to compare the set data for 1986 and 2016, the total extent of the sprawl in $\mathrm{km}^{2}$ was divided by the number of years within the period that is; 1986-2016. To assess the environmental impacts of urban sprawl in the study area, 5 points likert scale of measurement was used to elicit the respondents' opinion on the perceived impacts of the unprecedented growth of Awka town.

\section{Results and Discussion}

This section presents the results of analysis on the classes, extent of the urban sprawl, rate and magnitude of urban growth as well as perception on the environmental impact of urban sprawl in the study area. Table 1 shows the spatial extent of land use/land cover classes in the study area.

Table 1 shows land use/cover analysis in Awka for the period of 1986-2016.

Result in Table 1 shows that light vegetation witnessed a sharp decrease from $20,219.49 \mathrm{~km}^{2}$ (29.76\%) in 1986 to $4477.32 \mathrm{~km}^{2}$ (9.17\%) in year2000. It further decreased from $4477.32 \mathrm{~km}^{2}$ (9.17\%) to $1869.32 \mathrm{~km}^{2}$ (5.55\%) in 2016. This decrease is as a result of clearing of natural vegetation for urban development, thereby exposing the land to direct contact with rainfall, leading to gully erosion 
Table 1. Analysis of land use/cover in Awka for the years 1986, 2000 and 2016.

\begin{tabular}{ccccccc}
\hline \multirow{2}{*}{$\begin{array}{c}\text { Land use/cover } \\
\text { categories }\end{array}$} & \multicolumn{2}{c}{1986} & \multicolumn{2}{c}{2000} & \multicolumn{2}{c}{2016} \\
\cline { 2 - 7 } & $\mathrm{km}^{2}$ & $\%$ & $\mathrm{~km}^{2}$ & $\%$ & $\mathrm{~km}^{2}$ & $\%$ \\
\hline Light vegetation & $20,219.49$ & 29.76 & $4,477.32$ & 9.17 & 1869.32 & 5.55 \\
Farm land & $25,500.51$ & 37.53 & $17,848.44$ & 36.56 & $10,037.07$ & 29.82 \\
Dense vegetation & $15,010.02$ & 22.09 & $11,499.39$ & 23.55 & 9082.47 & 26.98 \\
Built-up Land & 3444.48 & 5.07 & 9431.64 & 19.32 & $11,452.46$ & 34.02 \\
Bare surface & 3761.37 & 5.54 & 5563.57 & 11.40 & 1219.74 & 3.62 \\
Total & $\mathbf{6 7 , 9 3 5 . 8 7}$ & 100.0 & $\mathbf{4 8 , 8 2 0 . 3 9}$ & 100.00 & $33,661.06$ & 100.00 \\
\hline
\end{tabular}

Source: NASRDA, 2017 and field exercise work, 2017.

in the area. The built-up area witnessed considerable increase throughout the study period occupying $3444.48 \mathrm{~km}^{2}$ (5.07\%) in $1986,9431.64 \mathrm{~km}^{2}(19.32 \%)$ in 2000 and $11,452.46 \mathrm{~km}^{2}(34.02 \%)$ in 2016. The results show that the urban growth of Awka metropolis varied with time and class of land use, while in 1986 and 2000 the growth rate is little, it became higher between 2000 and 2016 due to the population increase and development brought about creation of the new state capital.

This progressive increase in built-up area is in agreement with the work of Ade and Afolabi (2013) [12] on the other hand, farmland which occupied $10,037.07 \mathrm{~km}^{2}$ (19.13\%) of land in 1986 decreased to $25,500.51 \mathrm{~km}^{2}(48.60 \%)$ and $17,848.44 \mathrm{~km}^{2}(34.01 \%)$ in 2000 and 2016 respectively. The decrease in farmland throughout the study period must have been caused by the increase in built-up area which led to the conversion of farmlands to built-up lands. This is in line with the work of Nwafor (2006) [13] who also found that farmlands decreased as built-up area increased. Dense vegetation occupied 15,010.02 $\mathrm{km}^{2}(22.09 \%)$ in 1986 and decreased to11, $499.39 \mathrm{~km}^{2}(23.55 \%)$ in 2000 and to $9082.47 \mathrm{~km}^{2}$ (26.98) in 2016. Bare surface decreased progressively from $3761.37 \mathrm{~km}^{2}(5.54 \%)$ in 1986 to $1563.57 \mathrm{~km}^{2}(11.40 \%)$ in 2000 and $219.74 \mathrm{~km}^{2}$ (3.62\%) in 2016. Figures $2-4$ shows the land use/ land cover classification of the study area for the years 1986, 2000 and 2016.

The extent of urban land use has experienced progressive increase throughout the study period as shown in Table 1 . The year 1986 which represents the development that took place prior to the time the study area became the administrative Local Government Area, had the least aerial coverage of urban land use $12.78 \mathrm{~km}^{2}$ (10.40\%). This was preceded by the year 2000 (14 years later) where the extent of urbanization rapidly increased to $33.02 \mathrm{~km}^{2}$ (26.89\%). This rapid increase could however be accounted for by the increase in the construction of government offices, academic institutions, Health centres, housing facilities as well as the influx of the rural population coming for white collar jobs as well as business opportunity in the study area. More urban expansion resulting from continuous dividends of democracy which increased administrative and commercial activities resulted in an increase in the extent of urban area to $48.49 \mathrm{~km}^{2}$ 


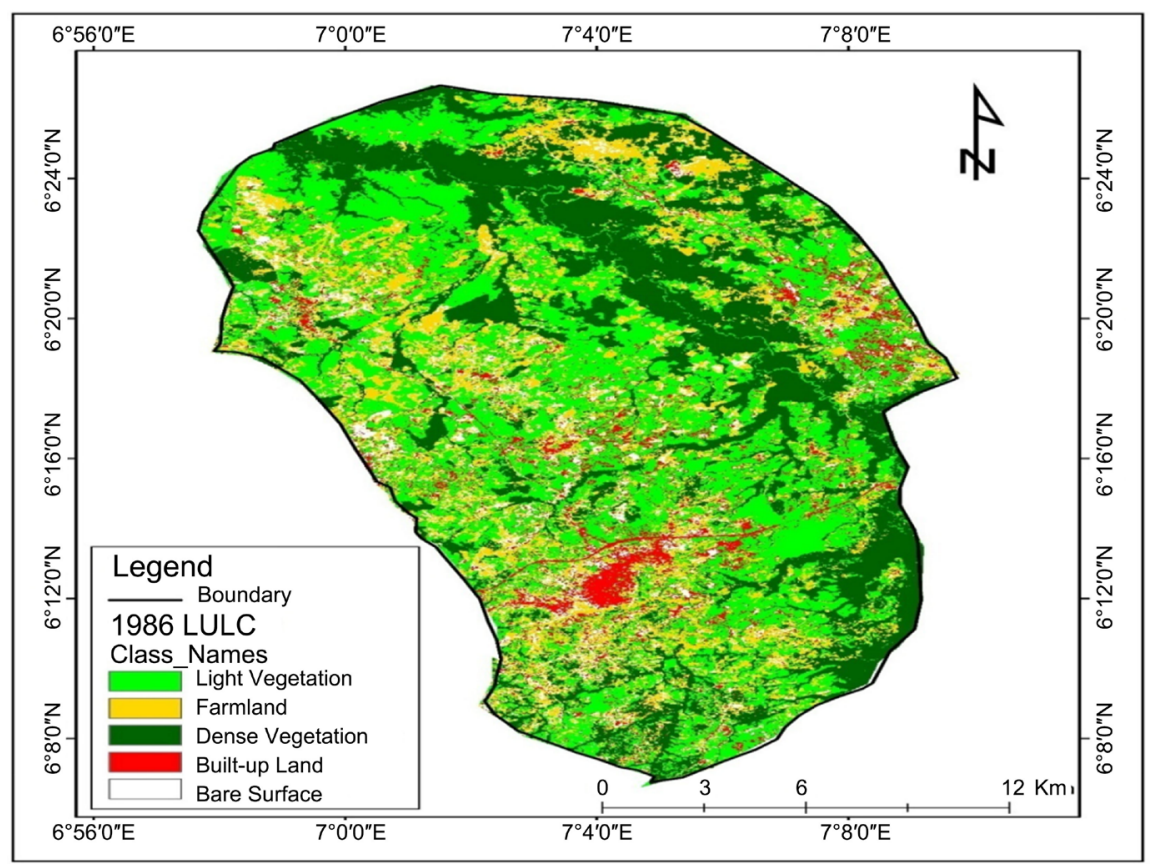

Figure 2. Classified land use/cover map of study area in 1986. Source: Source: NASRDA, 2017 and field exercise work, 2017.

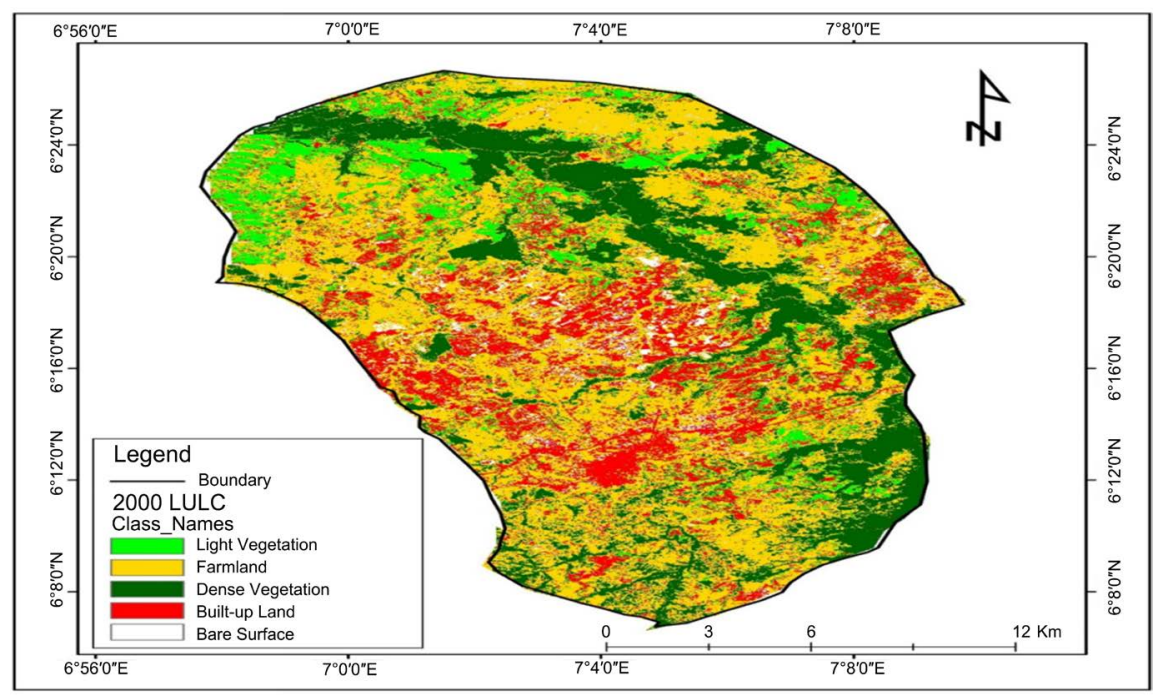

Figure 3. Classified land use/cover map of the study area in 2000. Source: NASRDA, 2017 and field exercise work, 2017.

(39.49\%) in 2016 as observed by Balzerek (2003) [14] that high construction activities and its structural as well as functional development lead to a yearly increase in built-up areas every year, just as in the case of Awka Metropolis which is not exceptional.

Table 2 shows the Extent and magnitude of change of urban sprawl in the study from 1986-2016.

The conversion of farmland to build up area is rapid in Awka metropolis between 1986 and 2016 as shown in Table 2 and illustrated in Figures 2-4. 


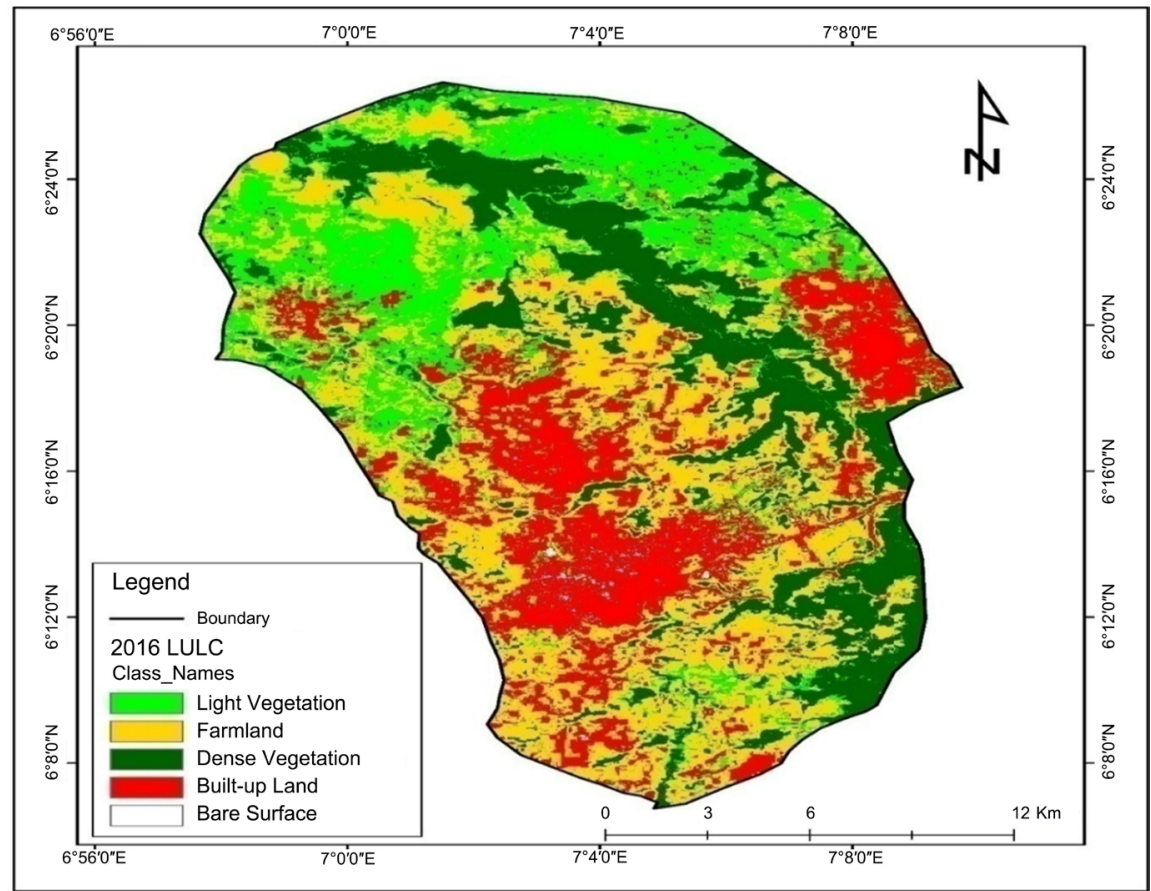

Figure 4. Classified land use/cover map of the study area in 2016. Source: NASRDA, 2017 and field exercise work, 2017.

Table 2. Extent and magnitude of change of urban sprawl in the study from 1986-2016.

\begin{tabular}{|c|c|c|c|c|c|}
\hline \multirow[b]{2}{*}{ Categories } & A & B & $\mathrm{C}$ & $\mathrm{D}$ & $\mathrm{E}$ \\
\hline & $1986\left(\mathrm{KM}^{2}\right)$ & $2000\left(\mathrm{KM}^{2}\right)$ & $2016\left(\mathrm{KM}^{2}\right)$ & $\begin{array}{c}\text { Magnitude of change } \\
\text { between } 1986 \text { and } \\
\text { year } 2000(\mathrm{~B}-\mathrm{A})\end{array}$ & $\begin{array}{l}\text { Magnitude of change } \\
\text { between year } 2000 \text { and } \\
2016(C-B)\end{array}$ \\
\hline Light Veg. & $20,219.49$ & 4477.32 & 1869.32 & $-15,742.17$ & -2608 \\
\hline Farm land & $25,500.51$ & $17,848.44$ & $10,037.07$ & -7652.07 & -7811.37 \\
\hline Dense Veg. & $15,010.02$ & $11,499.39$ & 9082.47 & -351063 & -2416.92 \\
\hline Built-up & 3444.48 & 9431.64 & $11,452.46$ & +5987.16 & +2020.82 \\
\hline Bare Sur. & 3761.37 & 5563.57 & 1219.74 & +1802.2 & -4343.83 \\
\hline Total & $67,935.87$ & $52,472.43$ & $33,661.06$ & $-56,797.58$ & $-15,159.3$ \\
\hline
\end{tabular}

Source: NASRDA, 2017 and field exercise work, 2017.

Results in Table 2 shows that farmland decreased drastically in magnitude between the year 1986 and year 2000 is $-7652.07 \mathrm{~km}^{2}$ while between year 2000 and 2016 is $-7811.37 \mathrm{~km}^{2}$. The built-up area on the other hand witnessed a significant increase in magnitude from $+5987.16 \mathrm{~km}^{2}$ between the years $1986-2000$ and $+2020.82 \mathrm{~km}^{2}$ in years $2000-2016$. Vegetation cover recorded decline in magnitude $\left(-36,680.17 \mathrm{~km}^{2}\right)$ between the years $1986-2000$ and $-5024.92 \mathrm{~km}^{2}$ between year 2000-2016). Bare surface witnessed a considerable increase in magnitude between the years 1986-200 $\left(+1802.2 \mathrm{~km}^{2}\right)$ and later declined from the year 2000-2016 (-4343.83). This result implies that between the period of 1986 and 2016, there is a decrease in agricultural activities likely due to the 
changes in the occupation of the work force in the area. The people are taking advantage of the business environment for employment opportunity. To buttress this point, this study in Table 1 revealed a decrease in farmland.

The increase in bare surface between the years 1986-2000 is as a result of clearing of natural vegetation for urban development, thereby exposing the land to direct contact with rainfall, leading to gully erosion in the area.

\subsection{Growth Trend and Pattern of Awka Metropolis}

Awka metropolis witnessed a remarkable growth between 1986 and 2016 to have more than tripled spatially from mere $3444.48 \mathrm{Km}^{2}$ in 1986 to about $11,452.46$ $\mathrm{Km}^{2}$ in 2016 as shown in Figure 3 \& Figure 4.

This growth is attributed to the sharp decline in farmland from $25,500.51 \mathrm{~km}^{2}$ (37.53\%) in 1986 to $1788.44 \mathrm{~km}^{2}$ (36.56\%) in 2000 and further declined to $10,037.07 \mathrm{~km}^{2}(29.82 \%)$ in 2016 . The reduction in farmlands is a result of encroachment on agricultural lands by developmental projects such as roads, houses, markets, school amongst others that has taken place over time. The sharp decline in both light and dense vegetation is attributed to increase in built-up land in the area. Light vegetation witnessed a considerable decline from $20,219.49 \mathrm{~km}^{2}(29.06 \%)$ in 1986 to $4477.32 \mathrm{~km}^{2}$ (9.17\%) in 2000 and further reduced to $1869.32 \mathrm{~km}^{2}(5.55 \%)$ in 2016 . Dense vegetation also witnessed a decline from $15,010.02 \mathrm{~km}^{2}(22.09 \%)$ in 1986 to $11,499.39 \mathrm{~km}^{2}$ (23.55\%) in the year 2000 and $9082.47 \mathrm{~km}^{2}$ (26.98\%) in 2016. Over the years, bare surface increased slightly from $3761.37 \mathrm{~km}^{2}$ (55.54\%) in 1986 to $5563.57 \mathrm{~km}^{2}$ (11.00\%) in the year 2000 and recently witnessed a decline from $5563.57 \mathrm{~km}^{2}$ to $1219.74 \mathrm{~km}^{2}(3.62 \%)$ in 2016. The decline in these land use types is mainly as a result of urban expansion over the period of 30 years.

The period of thirty (30) years from 1986 to 2016 witnessed considerable increase in population in the study area, this can be inferred from the fact that the land area covered by built-up area, comprising of residential, commercial, industrial and institutional land uses are on the increase, thereby affecting other land use/cover categories. For instance, the maps confirmed that built up areas increases from $5.07 \%$ to $19.32 \%$ from 1986 and 2000 . Further increase from $19.32 \%$ to $34.02 \%$ was witnessed from 2000 to 2016 as shown in Figure 5.

The results of analysis on Figures 2-4 show that most of the areas with mixed land uses are unplanned, with high density developments within towns such as Ifite, Okpuno, Mbakwu, Ntoko, Ndikpa, Ndiora, Isiagu, Nibo, Urumi and Umunike. Awka town is a major indigenous settlement that has grown organically without much planning and has the highest record of encroachments. The town accommodates many low income workers from neighboring local government areas.

\subsection{Perception on the Environmental Impacts of Urban Sprawl in the Study Area}

To further support the geospatial analysis for this study, it is important to consider 


\section{Growth from 1986 to $2016\left(\mathrm{Km}^{2}\right)$}

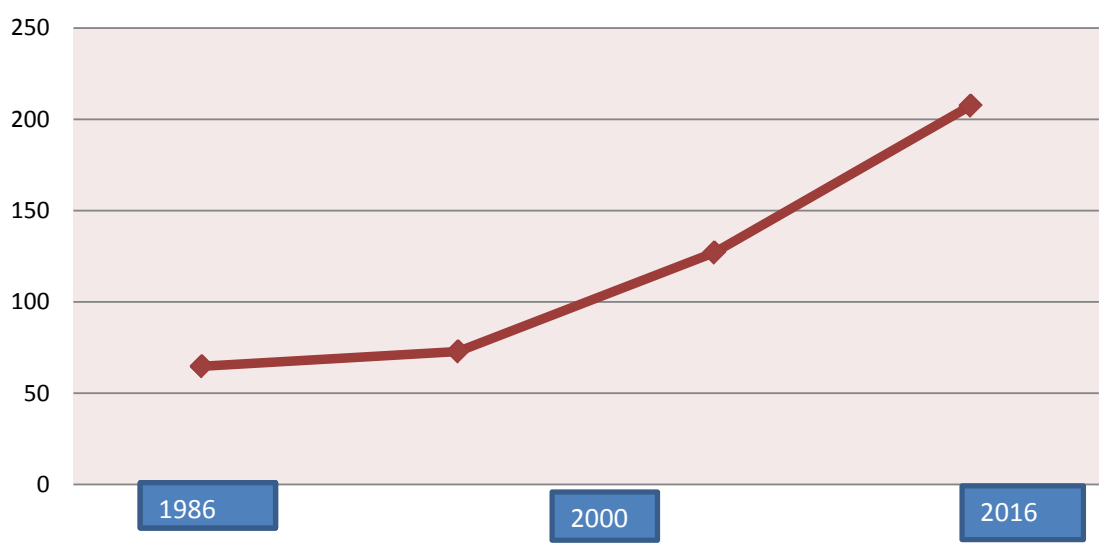

Figure 5. Trend of spatial growth of Awka from 1986 to 2016. Source: NASRDA, 2017 and field exercise work, 2017.

the perception of people's of the study area on the environmental impacts of the urban sprawl, this was achieved by employ the liker scale form of measurement to elucidate information from the respondents, keeping in view the technology and techniques used in this research. It was thought to be a better idea not to rely solely only on remote sensing and GIS approach to examine the sprawl but also to assess its impact on the environment.

Respondents were asked the impacts of urban sprawl in Awka in order to identify possible effects other than the changes in land use classes as observed using the GIS techniques and there responses are presented in Table 3.

Results on Table 3 shows that $72 \%$ of the respondents strongly agreed that urban sprawl resulted to loss of farmlands and wildlife while no respondent strongly disagreed. This is in accordance with the findings on Table 1 where farmland reduced drastically from $25,500.51 \mathrm{~km}^{2}$ in the year 1986 to $1003.7 \mathrm{~km}^{2}$ in the year 2016. However, $2.4 \%$ of the respondent disagreed and $10.1 \%$ were indifferent. In the same vein, $15.5 \%$ of the respondent agreed that loss of farmlands and wildlife was a great impact of urban sprawl in Awka metropolis.

Urban sprawl caused Pollution (Air, Water and Noise) in the study area. This was strongly agreed by $77 \%$ of the respondents while $17.8 \%$ agreed. The proportion of respondents who agreed and who strongly agreed put together is $94.8 \%$. The percentage of respondents who strongly disagreed was 0.6 while those who responded indifferently were just $4.2 \%$. This assertion by the respondents agree with the result in Table 3 where built-up area increased from $3444.48 \mathrm{~km}^{2}$ in year 1986 to $11,452.46 \mathrm{~km}^{2}$ in the year 2016. This built-up area with human activities led to increase in air, water and noise pollution in the metropolis.

Pressure on available facilities and poor waste management practices was perceived to be as a result of unprecedented growth of Awka town between 1986-2016. Respondents who strongly agreed constituted $72.6 \%$ while $19 \%$ agreed. Respondents who were indifferent (that is those who neither agreed nor disagreed) represent $5.9 \%$ of the respondent while those who strongly greed and those who 
Table 3. Environmental impacts of urban sprawl.

\begin{tabular}{|c|c|c|c|c|c|c|c|c|c|c|c|c|}
\hline $\mathrm{S} / \mathrm{N}$ & Possible impacts of urban sprawl & & & & & & & & & & & \\
\hline & & SA & $\%$ & AG & $\%$ & IDF & $\%$ & DA & $\%$ & SDA & $\%$ & Total \\
\hline 1 & Loss of farm lands and wild life & 121 & 72 & 26 & 15.5 & 17 & 10 & 4 & 2.4 & - & 0 & 168 \\
\hline 2 & Pollution (Air, Water and Noise) & 129 & 77 & 30 & 17.8 & 7 & 4.2 & 1 & 0.6 & 1 & 0.6 & 168 \\
\hline 3 & $\begin{array}{l}\text { Pressure on facilities and poor waste } \\
\text { management practices }\end{array}$ & 122 & 72.6 & 32 & 19 & 10 & 5.9 & 3 & 1.8 & 1 & 0.6 & 168 \\
\hline 4 & $\begin{array}{l}\text { Traffic congestion, accidents and delay } \\
\text { in travel time }\end{array}$ & 132 & 79 & 36 & 21 & - & 0 & - & 0 & - & 0 & 168 \\
\hline 5 & $\begin{array}{l}\text { Increase in social vices such as Crime, } \\
\text { prostitution etc }\end{array}$ & 120 & 71.4 & 23 & 13.7 & 16 & 6.0 & 7 & 4.2 & 2 & 1.2 & 168 \\
\hline 6 & $\begin{array}{l}\text { Increase in house rents, and failure of } \\
\text { housing and land markets to provide } \\
\text { for land and housing requirements }\end{array}$ & 98 & 58 & 54 & 32 & 12 & 7.1 & 3 & 1.8 & 1 & 0.6 & 168 \\
\hline
\end{tabular}

Note: $\mathrm{SA}=$ Strongly Agreed, $\mathrm{AG}=$ Agree, $\mathrm{IDF}=$ Indifference, $\mathrm{DA}=$ Disagree, $\mathrm{SDA}=$ Strongly Disagree.

disagreed were $1.6 \%$ and $0.6 \%$ respectively. This perception concurred with the finding on Table 1 where the built-up area increased within the study period and bare surface decreased from $361.37 \mathrm{~km}^{2}$ at the base year to $1219.74 \mathrm{~km}^{2}$ in the year 2016 due to population increase of the study area.

Urban sprawl brought about Traffic congestion, accidents and delay in travel time in the study area, Road traffic accidents and delay in travel was gauged and the following responses were recorded. Majority (79\%) of the respondents strongly agreed that the rapid growth of Awka town brought about traffic congestion and other road related challenges in the town while $21 \%$ agreed. There was consensus in agreement as there was not even a single respondent who either strongly disagreed or disagreed and there was also no respondent who stood between agreement and disagreement (indifferent). This implies that increase in built-up area (see Table 1) resulted to influx of people into the town brought about traffic congestion and road accidents.

Urban sprawl also brought about increase in social vices such as Crime, prostitution and so on, in Awka town. Responses for this option are; strongly agreed $71.4 \%$, agreed $13.7 \%$, indifferent $6.0 \%$ strongly disagreed $4.2 \%$ and disagreed $1.25 \%$. This is true because influx of people from neigbouring Local Government Area in search of white collar jobs has resulted to the expansion of Awka town leading to reduction in bare surface and increase in built-up area. Also, the failure of housing to provide for housing requirements of the rapidly growing population is an implication of urban sprawl in Awka metropolis. Out of the 186 questionnaires administered, 98 respondents representing 58.4\% strongly agreed while 32\% agreed. Respondents who neither agreed nor disagreed were 12 representing $7.1 \%$ while $1.8 \%$ and $0.6 \%$ strongly disagreed and disagreed respectively.

\section{Conclusions and Recommendations}

This research work demonstrates the ability of geospatial techniques in the anal- 
ysis of urban sprawl. The results obtained from this study revealed that there has been a continuous increase in built-up areas throughout the study period. There has also been a progressive increase of urban sprawl both in terms of spatial extent and magnitude throughout the study period. The most dramatic increase and the continuous expansion experienced in built-up area are shown between 2000 and 2016. The upsurge in population of the area was enhanced in recent time by the desire of the state government to restore Awka metropolis to its master plan as the state capital by the demolition of all forms of illegal structures within its territory. However, other specific land uses are also identified such as commercial land use comprising of banks, markets and shopping complexes, serviced oriented activities such as retailing finished products and petrol filling stations. Industrial land uses include privately owned informal businesses like welding, furniture making, and general electrical and engineering works. It is difficult to determine the spread of these informal industries. The period of thirty (30) years from 1986 to 2016 witnessed considerable increase in population in the study area; this can be inferred from the fact that the land area covered by built-up area, comprising of residential, commercial, industrial and institutional land uses is on the increase, thereby affecting other land use/cover categories such as farmland, bare surface and vegetation in the study area.

This study proffered the following recommendations.

1) There is a need for regular monitoring of urban sprawl and development by the state Government in the study area especially with the aid of geospatial techniques for better decision making.

2) There is a need for all stakeholders like Ministry of Land and Survey, Ministry of Environment, State Development Board and NGOs in urban land use management to ensure strict adherence to urban land use legislations.

3) There is a need for a regular appraisal by the state government on analysis of urban dynamics and development using geospatial techniques so as to easily detect areas that are fast growing and need attention in the study area.

Government should encourage researchers to further carry out urban-related studies with socio-economic effect in the study area for a more in-depth understanding of the dynamics of urbanization.

\section{Conflicts of Interest}

The authors declare no conflicts of interest regarding the publication of this paper.

\section{References}

[1] Badiane, A. (2006) African Cities: Some Thesis for a New Beginning. Kings Plaza, Bosso, Minna.

[2] Malthus, T.R. (1798) An Essay on the Principle of Population, as It Affects the Future Improvement of Society. With Remarks on the Speculations of Mr. Godwin, M. Condorcet, and Other Writers. As Reprinted in Malthus (1960).

[3] Torrens, P.M. and Alberti, M. (2006) Measuring Sprawl. Working Paper Series. 
CASA Centre for Advanced Spatial Analysis, University College London, London. https://doi.org/10.5334/baw.73

[4] Torrens, P.M. and Alberti, M. (2002) Measuring Sprawl. Paper Presented to the Association of Collegiate Schools of Planning (CSP), Atlanta, GA, 1-13.

[5] Imhoff, M.L., (2000) The Use of Multi Source and Satellite and Geospatial Data to Study the Effects of Urbanization on Primary Productivity in the United States. Transactions in Geoscience and Remote Sensing, 38, 2549-2556. https://doi.org/10.1109/36.885202

[6] Berry, B.J.L. (1990) Urbanization. In: Turner, B.L., Clark, W.C., Richards, J.F., Mathews, J.T. and Myers, W.B., Eds., The Earth as Transformed by Human Action: Global and Regional Changes in the Biosphere over the Past 300 Years, Cambridge University Press, Cambridge. https://doi.org/10.1177/030913259301700340

[7] Daniels, T. (1999) When City and Country Collide: Managing Growth in the Metropolitan Fringe. Island Press, Washington DC.

[8] Bureau of the Census (2000) Census. Bureau of the Census, Washington DC.

[9] Atiqur, R., Maik, N., Alka, S. and Javed, M. (2009) Urban Population-Environment Dynamics in the Developing World: Case Studies and Lessons Learned. Committee for International Cooperation in National Research in Demography (CICRED), Paris, $316 \mathrm{p}$.

[10] Mbaya, L.A. (2012) A Study of Inter-Relationships among Gully Variables in Gombe Town, Gombe State, Nigeria. Wudpecker Journal of Geography and Regional Planning, 1, 001-006. https://doi.org/10.14738/aivp.53.3343

[11] Anderson, J.R., Hardy, E.E., Roach, J.T. and Witmer, W.E. (1976) A Land-Use and Land-Cover Classification System for Use with Remote Sensing Data. U.S. Geological Survey Professional Paper 964. U.S. Geological Survey, Reston, Virginia, 23. https://doi.org/10.3133/pp964

[12] Ade, M.A. and Afolabi, Y.D., (2013) Monitoring Urban Sprawl in the Federal Capital Teritory of Nigeria Using Remote Sensing and GIS Techniques. Ethiopian Journal of Environmental Studies and Management, 4, 82-95. https://doi.org/10.4314/ejesm.v6i1.10

[13] Nwafor, J.C., (2006) Environmental Impact Assessment for Sustainable Development: The Nigerian Journal on Agricultural and Food Security, 4, 9-16.

[14] Balzerek, H. (2003) Achievements and Problems in the Evolution of Urban Centers in Nigerian Savannah: Case Study of Gombe. Symposium of the Sonderforschungsbereich 268', 29th May 1999, Frankfort/Main, Germany: Persistence and Transformation between Chad Basin and Benue. http://www.rzuser.uni-heidelberg.de/ bu1/sfb/d1/Maiduguri/achievements.htm 